\title{
miR-107 Regulates Granulin/Progranulin with Implications for Traumatic Brain Injury and Neurodegenerative Disease
}

Wang-Xia Wang, Bernard R. Wilfred, Sindhu K. Madathil, Guiliang Tang, Yanling Hu, James Dimayuga, Arnold J. Stromberg, Qingwei Huang, Kathryn E. Saatman, and Peter T. Nelson

From the Department of Pathology and Division of Neuropathology, University of Kentucky Medical Center and the Sanders-Brown Center on Aging, University of Kentucky, Lexington, Kentucky

Granulin (GRN, or progranulin) is a protein involved in wound repair, inflammation, and neoplasia. GRN has also been directly implicated in frontotemporal dementia and may contribute to Alzheimer's disease pathogenesis. However, $G R N$ regulation expression is poorly understood. A high-throughput experimental microRNA assay showed that $G R N$ is the strongest target for miR-107 in human $\mathrm{H} 4$ neuroglioma cells. miR-107 has been implicated in Alzheimer's disease pathogenesis, and sequence elements in the open reading frame-rather than the $3^{\prime}$ untranslated region-of GRN mRNA are recognized by miR-107 and are highly conserved among vertebrate species. To better understand the mechanism of this interaction, FLAG-tagged Argonaute constructs were used following miR-107 transfection. GRN mRNA interacts preferentially with Argonaute 2. In vitro and in vivo studies indicate that regulation of $G R N$ by miR-107 may be functionally important. Glucose supplementation in cultured cells that leads to increased miR-107 levels also results in decreased GRN expression, including changes in cell compartmentation and decreased secretion of GRN protein. This effect was eliminated following miR-107 transfection. We also tested a mouse model where miR-107 has been shown to be down-regulated. In brain tissue subjacent to $1.0 \mathrm{~mm}$ depth controlled cortical impact, surviving hippocampal neurons show decreased miR-107 with augmentation of neuronal GRN expression. These findings indicate that miR-107 contributes to $G R N$ expression regulation with implica- tions for brain disorders. (AmJ Pathol 2010, 177:334-345; DOI: 10.2353/ajpath.2010.091202)

MicroRNAs (miRNAs), 22 nucleotide noncoding RNAs, play fundamental roles in the human brain. ${ }^{1-3}$ MiRNAs increase the complexity of gene expression regulation and may have helped drive human brain evolution. ${ }^{4,5}$ Endogenous miRNAs perform critical neuroprotective functions ${ }^{6-8}$ with possible direct relevance to many diseases in the brain and elsewhere. ${ }^{9-14}$

At the molecular level, miRNAs "target" mRNAs through partial hybridization, leading to changes in the rate of polypeptide formation. ${ }^{15,16}$ MiRNAs interact with mRNAs within microribonucleoparticles (miRNPs) ${ }^{17}$ using evolutionarily ancient molecular mechanisms. At the core of miRNPs, Argonaute (AGO) proteins bind directly to mature miRNAs. Four paralogous human AGO proteins (AGOs 1-4) help orchestrate miRNA activities. ${ }^{17,18}$ A single miRNA species, in association with AGO proteins, may target hundreds or even thousands of different mRNAs. ${ }^{19-21}$ Complex principles govern how metazoan miRNAs bind to mRNA targets, ${ }^{22}$ so predicting the physiological interaction of particular mRNA targets is a challenge. Current algorithms for predicting miRNA targets are imperfect and computational predictions tend to differ one from the other. Thus, the use of direct, experimental target identification strategies is important.

Identifying physiological miRNA targets is particularly relevant because the miRNA:mRNA interactions can be pertinent to human illness. Aberrant miRNA expression may contribute to the progression of neurodegenerative

Supported by grants R01 NS061933, K08 NS050110, and P30 AG028383 from $\mathrm{NIH}$, and Kentucky Spinal Cord and Head Injury Research Trust grant 7-20.

Accepted for publication March 12, 2010.

Supplemental material for this article can be found on http://ajp. amjpathol.org.

Address reprint requests to Peter T. Nelson M.D., Ph.D., Department of Pathology, Division of Neuropathology, and the Sanders-Brown Center on Aging, Rm 311, Sanders-Brown Center, 800 S. Limestone, University of Kentucky, Lexington, KY 40536-0230. E-mail: pnels2@email.uky.edu 
diseases. ${ }^{13,14,23,24}$ A specific miRNA, miR-107, is downregulated in Alzheimer's disease (AD) beginning very early in the disease. ${ }^{25}$

In the present study we sought to identify transcriptome-wide miR-107 targets in human cells. Co-immunoprecipitation (co-IP) experiments that pull down AGO proteins provide a method for characterizing miRNPs along with associated molecules. ${ }^{26,27}$ Using these assays, researchers have isolated multiple proteins, miRNAs, and mRNA targets from miRNPs. ${ }^{28-34}$ We used anti-AGO co-IP and downstream Affymetrix microarray analyses ("RIP-Chip" ${ }^{35,36}$ ), to identify miRNA targets. This is a direct method that has been rigorously validated, ${ }^{37}$ and that can help to guide future computational algorithms.

A notable miR-107 target that we found is GRN. This gene has been given multiple names, including granulin(s), progranulin, acrogranin, gp88, proepithelin, PC cell-derived growth factor, epithelial transforming growth factor, and granulin-epithelin precursor. ${ }^{38-42}$ To avoid confusion, we refer to the current consensus identifier "GRN" for the protein and "GRN" for the gene or mRNA. GRN has been implicated directly in frontotemporal dementias and also may contribute pathogenetically to more prevalent neurodegenerative disease processes including AD. ${ }^{43-46}$ In addition to its involvement in neurodegenerative diseases, GRN appears to be relevant in human cancers and a pivotal modulator of cell growth, inflammation, and wound repair. ${ }^{42,47}$

\section{Materials and Methods}

\section{Synthetic miRNA Precursors and Inhibitors}

miRNA precursors and inhibitors were purchased from Ambion (Ambion, Austin, TX). When co-transfection to cells, miRNA precursors were used at $25 \mathrm{nmol} / \mathrm{L}$, and miRNA inhibitors were used at $100 \mathrm{nmol} / \mathrm{L}$.

\section{Plasmids and Antibodies}

Full-length cDNA (including 5'UTR and $3^{\prime}$ UTR) cloned in pCMV6-XL5 plasmid vectors were obtained that express human GRN (GRN, NM_002087.2), $\beta$-site APP-cleaving enzyme 1 (BACE1, NM_012104.3), and $\alpha$-synuclein (SNCA, SC119919) (OriGene Technologies, Inc, Rockville, MD). Full-length microtubule-associated protein tau (MAPT) was cloned into PCMV6-XL5 by PCR cloning. Plasmids carrying only open reading frame portion of GRN, MAPT, and SNCA were generated by PCR cloning.

Antibodies used in this work are: anti-AGO $(2 \mathrm{~A} 8)^{48}$; Goat anti-human ProGRN antibody (AF2420) and BACE1 monoclonal antibody (MAB931) from R\&D systems (Minneapolis, MN); anti- $\beta$-Actin antibody (600401886) was purchased from Rockland (Gilbertsville, PA). Anti-FLAG M2 affinity gel was from Sigma (St. Louis, MO). Anti-MAP Tau and anti- $\alpha$-synuclein antibodies were generously provided by Dr. Peter Davies (Albert Einstein College of Medicine, New York, NY) and Dr. Virginia Lee (University of Pennsylvania, Philadelphia, PA).

\section{Transfections and Dual Luciferase Reporter Assays}

For RIP-Chip transfections, $\mathrm{H} 4$ cells (American Type Culture Collection, Manassas, VA) were plated in $10-\mathrm{cm}$ culture plates at a density of $2.5 \times 10^{6} /$ plate. Cells were transfected the next day with $25 \mathrm{nmol} / \mathrm{L}$ of "Pre-miRNA precursors" and Negative Control \#1 (Ambion, Austin, TX) using RNAiMAX (Invitrogen, Carlsbad, CA) according to manufacturer's instructions. Cells were cultured for 48 hours after transfection. $\mathrm{H} 4$ cell transfection and R/uc reporter activity analyses were performed following the protocol described in our previous report. ${ }^{25}$

\section{Co-IP of miRNPs with Anti-AGO Antibodies}

The RIP-Chip co-IP assay with validation has now been described in detail. ${ }^{37}$ Briefly, protein $\mathrm{G}$ agarose beads (Invitrogen, Carlsbad, CA) were incubated with monoclonal anti-AGO, ${ }^{48}$ or nonimmune mouse serum (Pierce Biotechnology, Rockford, IL). After binding, beads were then washed three times in PBS and twice in lysis buffer (25 $\mathrm{mmol} / \mathrm{L}$ Tris- $\mathrm{HCl}, \mathrm{pH} 8.0,150 \mathrm{mmol} / \mathrm{L} \mathrm{NaCl}, 2 \mathrm{mmol} / \mathrm{L}$ $\mathrm{MgCl}_{2}, 0.5 \% \mathrm{NP}-40$, and $5 \mathrm{mmol} / \mathrm{L}$ dithiothreitol). $\mathrm{H} 4$ cells were harvested 48 hours after transfection. Cell lysates were subjected to preclearance by incubation with preblocked protein $\mathrm{G}$ beads at $4^{\circ} \mathrm{C}$ for 60 minutes. An aliquot of lysate after preclearance, but before any co-IP, was removed for total RNA and protein analyses. The remaining lysates proceeded to co-IP with either 2A8-Protein G beads or nonimmune mouse serum-protein $G$ beads at $4^{\circ} \mathrm{C}$ for 90 minutes. After co-IP, the beads were washed at room temperature as follows: twice with lysis buffer; three times with lysis buffer containing $900 \mathrm{mmol} / \mathrm{L} \mathrm{NaCl}$ and $1 \%$ NP-40; twice more with lysis buffer, and then the beads were transferred to fresh $1.5 \mathrm{ml}$ tube, where there was one final wash with lysis buffer containing $0.05 \%$ NP-40. Following the washes, beads and lysates were subjected to DNase treatment by shaking/ incubating at $37^{\circ} \mathrm{C}$ for 20 minutes with $250 \mu$ of DNA digestion solution containing $40 \mathrm{mmol} / \mathrm{L}$ Tris- $\mathrm{HCl}, \mathrm{pH}$ 8.0, $10 \mathrm{mmol} / \mathrm{L} \mathrm{MgSO}_{4}, 1 \mathrm{mmol} / \mathrm{L} \mathrm{CaCl}, 200 \mathrm{U} / \mathrm{ml}$ RNasin, and $40 \mathrm{U} / \mathrm{ml}$ DNase I (Promega, Madison, WI). Co-IPed RNA, and also total RNA from lysates, were extracted using Trizol LS (Invitrogen, Carlsbad, CA) as described previously. ${ }^{25}$

\section{Microarray Analysis and Reverse Transcription Quantitative PCR}

Microarray analysis of RNAs isolated from co-IP or from total lysates were performed using Affymetrix Human Gene 1.0 ST chip at University of Kentucky Microarray Core Facility. Eight different biological replicates from three individual experiments were performed for each transfection condition. For quantitative (q)PCR analysis, RNAs were reverse-transcribed with qScript cDNA SuperMix (Quanta Biosciences, Gaithersburg, MD), amplified using TaqMan 2X PCR Master Mix (Applied Biosystems, Branchburg, NJ) and SYBR as detector. QPCR was 
performed using $\mathrm{ABI}$ Prism 7000 Sequence Detection System (Applied Biosystems, Foster City, CA). Data presented show the average of triplicates from qPCR. Specific GPCR primers were as follows: GRN (Forward) 5'-ATGCTGTGTGCTGCGAGGATC-3', GRN (Reverse) 5'GCGCCGATCAGCACAACAGA-3'; BACE1 (Forward) 5'-GAC TTCACAATGTTGGCCTGTCA-3', BACE1 (Reverse) 5'-CAGTCCGAGAATAACAACATAACCAG-3'; beta actin (Forward) 5'-GCGAGCATCCCCCAAAGTTCACA-3', beta actin (Reverse) 5'-GGCACGAAGGCTCATCATTCA-3'.

\section{Glucose Treatment and GRN Detection in Cell Culture Media}

Glucose treatment for $\mathrm{H} 4$ cells follow the method previously described. ${ }^{49} \mathrm{H} 4$ cells were incubated for 3 hours in Dulbecco's modified Eagle medium (without serum and glucose) containing $2 \mathrm{mmol} / \mathrm{L}$ sodium pyruvate. Cells were then incubated in either the same medium, or with added $10 \mathrm{mmol} / \mathrm{L}$ glucose. Cell culture media and cells were harvested after 16 hours treatment. Cell culture media were spun briefly to remove residual cells. GRN levels in cell culture media were determined using an enzyme-linked immunosorbent assay (ELISA) as described previously. ${ }^{50}$

\section{Reporter Assays of GRN mRNA Putative miR- 107 Binding Sites in Response to Glucose Treatment}

To assess the response of a putative miR-107 binding sequence (nucleotides 892-974 on NM_002087.2) in GRN to glucose, we first co-transfected $\mathrm{H} 4$ cells with pRL-TK reporter constructs bearing miR-107 MRE on GRN open reading frame (GRNwt) or its mutant (GRNmut), six replicates each. Cell culture medium was changed after 24 hours, and the cells were further incubated for 24 more hours. Glucose treatment was performed as described above, followed by conventional Dual Luciferase Reporter Assays. Data shown represents two individual experiments.

\section{Tissue Culture Immunocytochemistry and Semiquantitative Scoring of Staining}

30,000 H4 cells were seeded per well onto Lab-Tek II chamber slide system (Nalgene Nunc, Rochester, NY). The following day, transfection of miR-107 and negative control were performed as described above. 48 hours later, the media was aspirated and cells washed and then fixed using 4\% paraformaldehyde (10 minutes; Fisher, Pittsburgh PA). Cells were permeabilized with $0.3 \%$ Triton -X-100 (Fisher, Pittsburgh, PA) in PBS. Antibody blocking was performed in 5\% normal horse serum (Jackson Immunoresearch, West Grove, PA) in PBS, for 1 hour at room temperature. Blocking solution was aspirated and the cells were incubated overnight at $4^{\circ} \mathrm{C}$ in a primary antibodies including anti-GRN (1:300; same as de- scribed above) and anti-human GRP 78/BiP antibody (1:500; Cat. No. G8918, Sigma-Aldrich) diluted in 1\% normal horse serum in PBS. The next day, cells were washed $(P B S \times 3)$ and incubated in dark for 2 hours, with two secondary antibodies, diluted in 1\% normal horse serum: Texas Red conjugated IgG (Code No. 805-075180, Jackson Immunoresearch) and DyLight 488 conjugated IgG (Code No. 711-487-003, Jackson Immunoresearch) were used at $1: 800$ and 1:500. Following additional PBS washes, slides were mounted in Vectashield $(\mathrm{H}-1000$, Vector Laboratories Inc, Burlingame, CA). Stained slides were viewed by a researcher blinded to the treatment and staining protocols who took photomicrographs using a $\times 60$ objective, using both Texas Red and fluorescein isothiocyanate filters, for a total of 180 different high-power fields (1483 cells total) encompassing a number of controls, only a subset of which (253 cells) were double-labeled for GRN and GRP78. These images were then analyzed blindly by a different researcher who assessed image intensity, granularity of staining, and co-localization of granules on a semiquantitative scale (0 to 10).

\section{Controlled Cortical Impact Injury and Mouse Brain in Situ Hybridization, Immunohistochemistry, and Quantification of Staining}

Male C57BL/6 mice ( $n=7 ; 20$ to $25 \mathrm{~g}$ ) were anesthetized using isoflurane and subjected to $1.0 \mathrm{~mm}$ depth controlled cortical impact brain injury over the left parietal cortex as previously described in detail. ${ }^{51,52}$ All procedures involving animals were approved by the University of Kentucky Institutional Animal Care and Use Committee. Mouse brain in situ hybridization for miR-107 was performed as described in detail $7,53,54$ on perfusion-fixed (4\% paraformaldehyde) mice brains that were cut on a freezing microtome. Mice were euthanized 24 hours after injury, and brains were prepared for staining as previously described. ${ }^{52}$ Briefly, $40 \mu \mathrm{m}$-thick sections were stained with $0.5 \%$ Cresyl Violet (Nissl stain) or immunolabeled for GRN. After an overnight incubation with antiGRN antibody (Goat polyclonal, 1:300, R\&D systems, $\mathrm{MN}$ ), sections were incubated in biotin-conjugated IgG (Jackson Immunoresearch, PA) followed by avidin-biotinenzyme complex (Vector Laboratories, CA).

For image analyses, one brain section per animal was selected from the epicenter of the cortical impact $(-1.80$ $\mathrm{mm}$ Bregma). A digital image of this coronal section was captured at $\times 1.25$ magnification using an Olympus AX80 microscope. On sections stained for GRN, mir107 and Nissl substance, a researcher blinded to the experiment traced the pyramidal layers of CA1 and CA3 subfields separately within each hippocampus, contralateral and ipsilateral to the impact. The total staining intensity was quantified within each region on GRN or mir107 stained sections using Image-Pro Plus software (version 6.1.0.346, Media Cybernetics, Inc). The total area of Nissl-stained cells in each pyramidal layer region was then quantified. GRN and mir107 staining intensities were normalized to the total 
cellular area to correct for potential differences in cell density across animals.

\section{Results}

\section{RIP-Chip Assay Procedure}

RIP-Chip experiments were performed on $\mathrm{H} 4$ cancer cells, ${ }^{55}$ which have a partial glial/neuronal phenotype. ${ }^{56}$ $\mathrm{H} 4$ cells were first transfected with miR-107 and various miRNA transfection controls. A Northern blot analysis on co-IPed miRNPs showed that transfected miRNAs were incorporated specifically into the miRNP (Figure 1A). MiRNPs were co-IPed with anti-AGO antibodies bound to protein G-agarose beads. RNA associated with AGO protein complexes were then isolated for microarray profiling, to identify transcriptome-wide miR-107 targets in $\mathrm{H} 4$ cells.

After miR-107 transfections were shown to be successful, Affymetrix GeneChip microarrays were used to profile mRNAs that associated with miRNPs following miR-107 transfection. RNAs isolated from co-IPed miRNPs were at very high quality as determined by RIN (RNA Integrity Num-

\section{A} Northern blots after
miRNA transfections
and anti-AGO co-IP

\section{Probes}

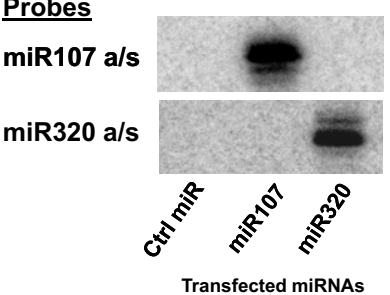

B

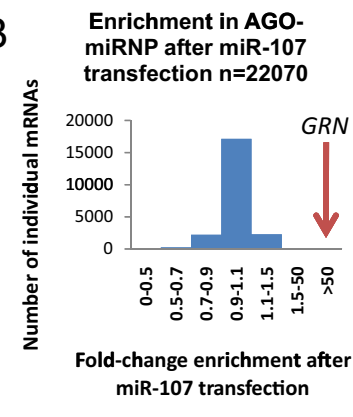

C

\begin{tabular}{|c|c|c|c|c|c|}
\hline \multirow{4}{*}{$\begin{array}{l}\text { Gene } \\
\text { Symbols }\end{array}$} & \multicolumn{4}{|c|}{$\begin{array}{l}\text { Fold mRNA enrichment relative to } \\
\text { negative control miRNA transfection }\end{array}$} & \multirow{4}{*}{$\begin{array}{l}\text { Target } \\
\text { Prediction? }\end{array}$} \\
\hline & anti-Ag & go Co-IP & & sate & \\
\hline & \multicolumn{4}{|c|}{ miRNA transfected } & \\
\hline & \begin{tabular}{|l|} 
miR-107 \\
\end{tabular} & miR-320 & miR-107 & miR-320 & \\
\hline GRN & 52.4 & 0.8 & 0.5 & 0.8 & None \\
\hline IER3IP1 & 33.4 & 0.9 & 0.7 & 1.0 & None \\
\hline RPLPO & 8.0 & 2.3 & 0.7 & 1.1 & None \\
\hline C22orf13 & 3.8 & 1.1 & 0.4 & 0.9 & None \\
\hline INSIG1 & 3.6 & 0.9 & 1.0 & 1.2 & None \\
\hline ZDHHC4 & 3.3 & 1.0 & 0.6 & 0.9 & None \\
\hline METRNL & 2.8 & 1.1 & 1.5 & 1.4 & None \\
\hline RPL27 & 2.7 & 1.3 & 1.0 & 1.1 & None \\
\hline SAT1 & 2.6 & 1.6 & 2.8 & 1.2 & None \\
\hline CSNK1G2 & 2.5 & 1.4 & 0.3 & 1.0 & TS, PT \\
\hline NINJ1 & 2.5 & 3.2 & 0.8 & 1.0 & None \\
\hline
\end{tabular}

Figure 1. RIP-Chip identified GRN as a novel target of miR-107. A: Northern blots on RNA from $\mathrm{H} 4$ cells harvested two days after transfection and following anti-AGO co-IP show that transfected miR-107 and miR-320 were incorporated specifically into miRNPs. B: RIP-Chip identifies GRN mRNA as the strongest target recruited to the microribonucleoparticle (miRNP) following transfection with miR-107. The relative enrichment for GRN in the miRNP following miR-107 transfection is $>50$-fold, which held consistently across all experiments. The vast majority of mRNAs were not enriched in the miRNP following miR-107 transfection (see also Supplemental Figure S1 at $b t t p: / /$ ajp.amjpathol.org). C: GRN and the other top 10 enriched mRNAs following miR-107 transfections. Levels of these miR-107 targets in miRNPs following miR-320 transfection are shown in parallel. Relative levels of mRNA in the cell lysates before the co-immunoprecipitation are also listed. The right-most column shows whether these mRNAs were predicted as miR-107 targets by computational miRNA target prediction websites MicroCosm (MC), TargetScan (TS), or PicTar (PT). $62-64$ ber 10.0) in all samples. Eight different biological replicates, in three different batches, were performed for both miR-107 and control miRNAs. RIP-Chip indicated consistently-in every experiment without exception - that GRN was the mRNA target most strongly incorporated into the miRNP following miR-107 transfection (Figure 1, B-C). By contrast, GRN mRNA was not enriched in miRNPs following transfections with miR-124, miR-128, or miR-320 (data from RIPChip with these other miRNAs, and more rigorous assay validation, will be published in a separate manuscript). There was a consistent $\sim 50$-fold enrichment in miRNPs after miR-107 transfection, with less GRN mRNA in the lysate. This represented an extreme enrichment considering that over $99.9 \%$ of the mRNAs were enriched $<4$-fold, and most not at all, in the assay. Since GRN mRNA levels were above average in the miRNP before miR-107 transfection, the fold-change results are not due to an artifact of low

\section{A Western blots after miRNA transfections}

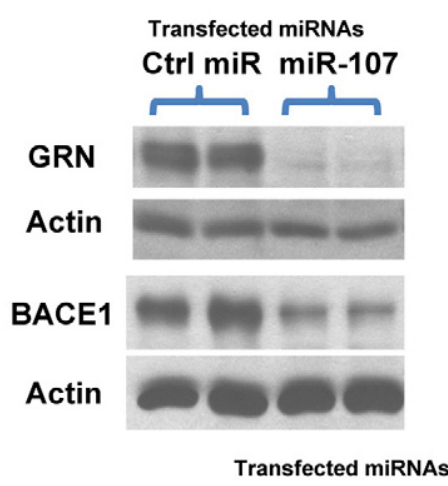

B

mRNAs levels in lysate and anti-AGO co-IP: effect of miR-107 transfection

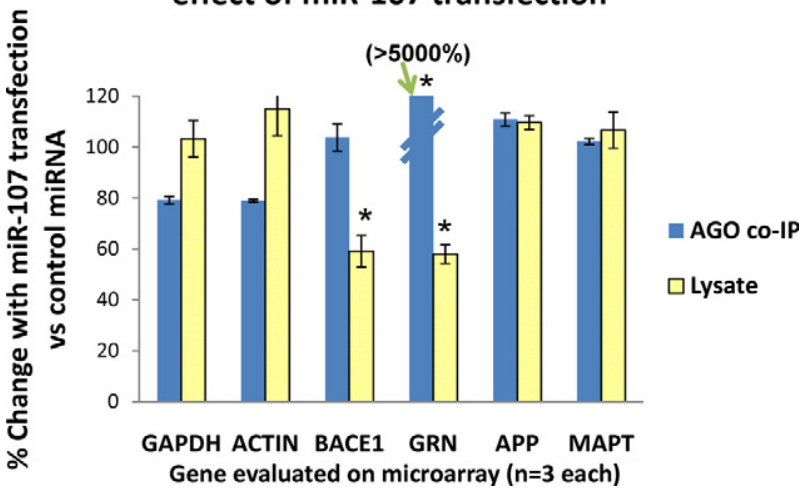

Figure 2. Western blots and mRNA analyses. MiRNA transfections and Western blots were used to evaluate the effects of miR-107 transfections on gene products identified by RIP-Chip. Two days after transfection with miR-107 or negative control miRNAs, $\mathrm{H} 4$ cells were harvested and Western blots were performed. A: Co-transfection of pCMV6-GRN and pCMV6-BACE1 with miR-107 or negative control miRNA showed that relative to the control miRNA, GRN, and BACE1 proteins were knocked down in cells after miR-107 transfection, but $\beta$-Actin protein levels were not changed. B: Results of microarray experiments comparing miR-107 transfection versus negative control miRNA, for "housekeeping" genes GAPDH and $\beta$-Actin, GRN $B A C E 1$, and two other genes relevant to neurodegenerative disease, $A P P$ and $M A P T$. Each bar represents three biological replicates; error bars are SD. Only $B A C E 1$ and GRN show decreased mRNA in the cell lysates $\left({ }^{*} P<0.01\right)$ following miR-107 transfection relative to a negative control miRNA transfections, and only GRN shows an enrichment in the miRNP following miR107 transfection (arrow: $P<0.0001$ ). BACE1 was not enriched in miRNPs. 
mRNA levels at baseline (see Supplemental Figure S1 at http://ajp.amjpathol.org).

To test whether the changes seen in RIP-Chip are manifest also by altered protein levels in tissue cultured cells, Western blots were performed after miR-107 cotransfections with full-length GRN and BACE1 expressing plasmids. Augmenting miR-107 leads to strong reduction in GRN expression (Figures 2A, and 3). There was also a clear knock-down of previously identified miR-107 target BACE $1^{25}$ protein levels after miR-107 transfection.

The top ten miR-107 targets identified by RIP-Chip are shown in Figure 1C (see Supplemental Table S1 at http:// ajp.amjpathol.org for the complete list of miR-107 targets). These are mRNAs that show decreased levels of mRNAs in the lysate and enriched mRNA levels in the miRNP. The correlation was poor between RIP-Chip identified genes and the computerized prediction algorithms for these top targets (Figure 1C). Of the strongest miR-107 targets identified by RIP-Chip, only two were predicted to be miR-107 target according to computational algorithms that assume 3'UTR miRNA binding. Further studies were performed to provide context and validation for the exceptional recruitment of GRN mRNA into the miRNP following miR-107 transfection in $\mathrm{H} 4$ cells. mRNA from the co-IPs and the lysates (total RNA isolated before co-IP) were evaluated separately via microarrays. Figure $2 \mathrm{~B}$ shows how the mRNA levels were affected after miR-107
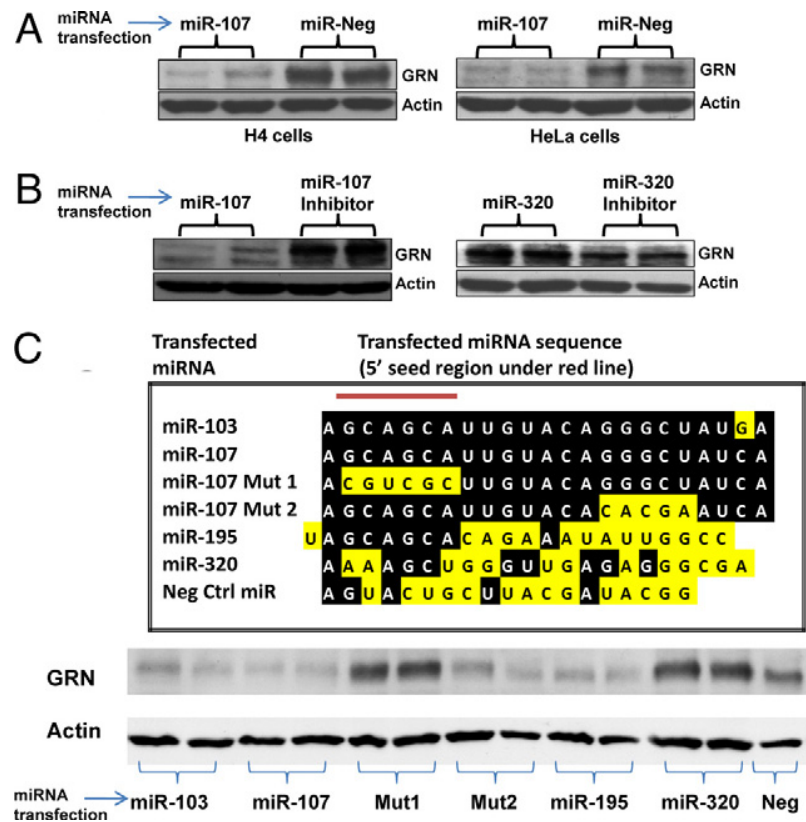

Figure 3. miR-107 interactions with GRN mRNA appear to be mediated through the 5 seed region of miR-107. Transfections of miRNA confirm that miR-103 and miR-107 target GRN. Endogenous GRN protein expression levels are detected in $\mathrm{H} 4$ cells and HeLa cells. A: Western blot analysis demonstrate that miR-107 transfections, but not a control miRNA in both H4 and HeLa cells, cause knockdown of endogenous GRN without affecting $\beta$-actin levels. B: Higher GRN expression is seen after miR-107 inhibitor transfection, whereas miR-320 inhibitor does not increase GRN expression. C: To better understand the sequence determinants of miR-107:GRN interaction, multiple miRNA sequences were assessed; sequences of transfected miRNAs are shown (upper panel). The $5^{\prime}$ seed regions (nucleotides 2 to 7 ) are indicated. At bottom, Western blots show GRN protein expression after miRNA transfections. Note that all of the transfected miRNAs with the $5^{\prime}$ seed region of miR-107 knock down GRN. transfection relative to a different control miRNAs according to the microarray data. Included in the analyses were "housekeeping" genes (GAPDH and $\beta$-actin) and genes related to neurodegenerative diseases (APP, BACE1, and MAPT). We have previously shown that miR-107 targets $B A C E 1^{25}$. Although miR-107 transfection leads to decreased BACE1 mRNA in the lysate, there is no increase of BACE1 mRNA in the miRNP following miR-107 transfection (see Discussion).

\section{Examining miR-107:GRN mRNA Interaction Using Additional Transfection Experiments}

To further characterize the interaction between miR-107 and the GRN mRNA, we analyzed the results of miRNA transfections on endogenous GRN expression (Figure 3, A and B). In both $\mathrm{H} 4$ cells and HeLa epithelial cells, miR-107 transfection but not a negative control miRNA or miR-320 caused endogenous GRN expression to decrease. Higher GRN expression was seen in cells transfected with a miR-107 inhibitor but not miR-320 inhibitor. Next, we tested further the sequence determinants of miR-107 inhibition of GRN expression using seven different miRNAs (Figure 3C). Sequences of transfected miRNAs are shown. miR-103 differs from miR-107 only at a single nucleotide near the $3^{\prime}$ end. A more distant paralog also expressed in humans, miR-195, shares the 5' seed region with miR-107 but is otherwise dissimilar. Two additional, nonphysiological miR-107 derived mutant miRNAs were synthesized for transfection experiments: "miR-

\section{A}

Human GRN (NM_002087) mRNA:
5'UTR: nts 1-219
Open reading frame: nts 220-2001
"Seed" sequences (U G C U G C/U) on mRNA that are
conserved between humans, frogs, and zebrafish

B
Proteins expressed from full-length cDNA constructs

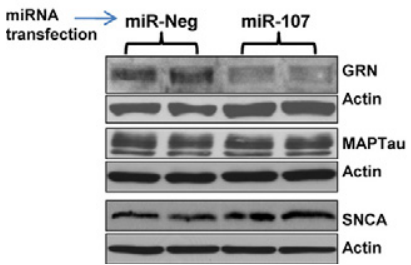

Proteins expressed from ORF cDNA constructs

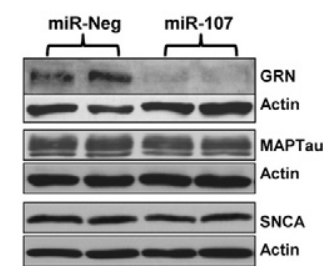

Figure 4. miR-107 interacts with the open reading frame of $G R N$ mRNA. A $G R N$ mRNA cartoon, with the 5'UTR, open reading frame, and 3'UTR roughly to scale. Note the relatively small $5^{\prime}$ UTR and $3^{\prime}$ UTR. Most computational miRNA target prediction databases with miRNA prediction algorithms do not predict that GRN is a target for miR-107. However, sequences complementary to the $5^{\prime}$ seed of miR-107 are present in the open reading frame and conserved from zebrafish to humans. B: To examine the target location of miR-107, full-length CDNA and only open reading frame expressing pCMV6XL5 plasmids of GRN, MAPT, and SNCA were co-transfected with miR-107 or a negative control miRNA. Western blot analyses were performed to examine miR-107 effects on these proteins. GRN expressed from both full-length and open reading frame carrying plasmids were clearly knocked down by miR107 , indicating that miR-107 target sites are located in the open reading frame of GRN. Expression of MAPT and SNCA from either full length or open reading frame constructs were not affected by miR-107, indicating that miR107 targeting GRN is specific and not related to the plasmid vector. 
107 Mut 1" differs from miR-107 in the $5^{\prime}$ seed region, whereas "miR-107 Mut 2" differs from miR-107 in the 3' portion. Two other control miRNAs, miR-320 and a negative control miRNA, were also tested. These experiments show that the $5^{\prime}$ seed region of miR-107 is necessary to induce strong knockdown of the full-length GRN mRNA, whereas the 3'region of miR-107 contributes less.

The next question related to the sequence(s) in GRN mRNA that are recognized by miR-107. Full length GRN mRNA comprises $\sim 2300$ nucleotides (nts). As shown in Figure 4A, GRN mRNA has a relatively short 3' UTRfewer than $300 \mathrm{nts}$, versus $\sim 750 \mathrm{nts}$ average for human mRNAs. ${ }^{57}$ The 5 ' seed sequence of miR-107 (GCAGCA) should bind an antiparallel complementary target mRNA sequence (UGCUGC) in GRN mRNA. An extraordinary number of these sequence iterations are present in GRN mRNA-UGCUGC (20 iterations) and UGCUGU (11 iterations; the latter uridine could allow miRNA hybridization through $\mathrm{G}: \mathrm{U}$ binding ${ }^{21}$ ). For perspective, $\beta$-Actin mRNA $(\sim 1800$ nts $)$ has only one each of UGCUGC and UGCUGU sequences, and APP mRNA ( 3600nts) has four UGCUGC and one UGCUGU sequence.

UGCUGC sequences are present in the open reading frame of human GRN mRNA (Figure 4A). This suggests a testable hypothesis: miR-107 may target open reading frame sequences. pCMV6-XL5 expression plasmids were constructed to carry only the open reading frames of GRN, MAPT, and SNCA. (MAPT and SNCA were chosen only because each is associated with neurodegenerative diseases.) As with the full-length GRN CDNA clone, GRN protein expressed from a plasmid containing only the open reading frame of GRN mRNA were also

\section{A

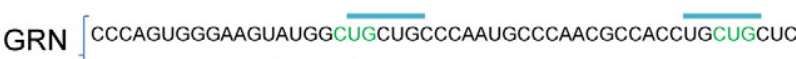 wt CGAUCACCUGCACUGCUGCCCCCAAGACACUGU}
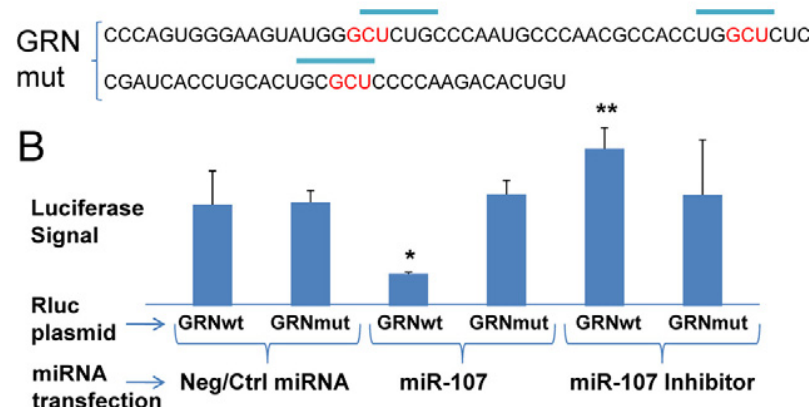

Figure 5. Validation of miR-107 potential target sites in GRN mRNA open reading frame. Dual luciferase reporter assays were used to validate miR-107 target sites on GRNmRNA. A: A sequence in the GRNmRNA open reading frame (nucleotides 892 to 974 on NM_002087.2) that contains three UGCUGC iteration (top), and a mutated sequence (bottom), were subcloned into the $3^{\prime}$ UTR of Renilla luciferase (Rluc) reporter constructs. UGCUGC iterations are indicated with blue lines. Note that in the GRNmut plasmid, there are only three 3-nucleotide sequences changed (green sequences in GRNwt were changed to red sequences in GRNmut), to alter the predicted seed-binding sequences. B: Reporter plasmids were co-transfected with a negative control miRNA, miR-107, or miR-107 inhibitor ( $N=3$ for each condition, with PGL3 transfections to control for transfection efficiency). Luciferase signal, adjusted for transfection efficiency, is in arbitrary units. In these experiments, Rluc reporter with the the GRNwtcontaining sequence is knocked down with miR-107 transfection, but not the GRNmut. ${ }^{*} P<0.001$ and ${ }^{* *} P<0.1$ using Student's $t$-test. down-regulated after miR-107 co-transfection. In contrast, MAPT and SNCA protein expressed from pCMV6XL5 plasmids carrying either full-length CDNA or only open reading frames were not down-regulated by miR107 (Figure 4B). This experiment indicates that the effect of miR-107 on GRN mRNA is specific, and at least some miR-107 target sequences are present in the mRNA's open reading frame.

We tested directly whether a sequence in the human GRN mRNA containing three of the UGCUGC tandems may constitute a target for miR-107. Dual luciferase reporter assays were used (Figure 5). An $82 \mathrm{nts}$ portion of the GRN mRNA open reading frame (GRNwt), corresponding to nts 892-974 on NM_002087.2, was subcloned into the 3' UTR of pRLTK-R/uc plasmid (Figure 5A, top). The same plasmid construct with only nine different nucleotide changes (GRNmut), but with identical overall A/G/C/U content, was created as a control (Figure 5A, bottom). Rluc plasmids were co-transfected with miR107, a negative control miRNA, or a miR-107 inhibitor. The GRNwt reporter construct, but not GRNmut, had luciferase expression knocked down by miR-107 (Figure $5 B$ ). These results provide support for the hypothesis that the UGCUGC iterations in the GRN mRNA open reading frame are target sites of miR-107.

As they are potential miR-107 targets, GRN mRNA's 31 UGCUGC and UGCUGU sequences can be the basis for

\section{FLAG-AGO co-IPs show enrichment for GRN mRNA with AGO2 miRNPs}

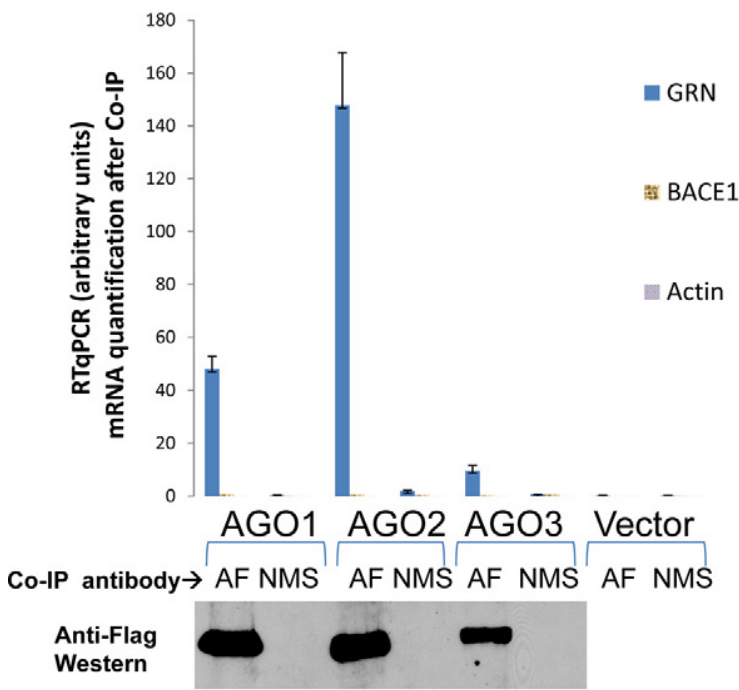

(AF=Anti-FLAG; NMS=Non-immunized mouse serum)

Figure 6. Differential association of $G R N$ with FLAG-tagged human Argonaute (AGO). FLAG-tagged AGO constructs ${ }^{58}$ were co-transfected with miR107 to test for differential distribution of miR-107 targets GRN and BACE1 in different AGO paralogs. Following co-transfections, lysates were co-IPed using either anti-FLAG (AF) antibody or nonimmunized mouse serum. RNAs that associated with miRNPs were subjected to reverse transcription-qPCR. qPCR results were normalized to total RNA levels. Note that GRN mRNA is strongly associated with AGO2, followed by AGO1. By contrast, neither BACE1 nor $\beta$-Actin mRNAs are enriched in the FLAG-AGO co-IPs. These data suggest different pathways for miR-107 targeting BACE1. miR-107 regulation of BACE1 may be through a different mechanism than that of GRN because BACE1 mRNA does not apparently associate stably with AGO 1-3 in H4 cells. Western blots analysis using AF antibody are shown for co-IPed miRNPs. 
estimating preliminarily the phylogenetic conservation of the miR-107:GRN mRNA interaction. Sequence alignments were made between human, frog, and zebrafish GRN mRNAs to encompass widely-divergent vertebrate phyla. (miR103 and miR-107 sequences are identical in humans, frog, and zebrafish.) Remarkably, 14 of the 31 human UGCUGC/ UGCUGU sequences were also conserved between these three divergent species (Figure 4A and see Supplemental Figure S2 at $h$ ttp://ajp.amjpathol.org for complete alignment data). Each of these potential miR-107 recognition element sequences was in the GRN mRNA open reading frame. Together with our transfection experiments, these data indicate that miR-107 interacts with GRN mRNA at least partly through the $5^{\prime}$ miRNA seed and the open reading frame GRN sequences underlying this interaction appear wellconserved among vertebrate species.

We caution that both UGC and UGU are codons for the amino acid cysteine, and GRN is a highly cysteine-rich protein. However, most other top mRNA targets for miR-107 are not cysteine-rich proteins, and of 16 mRNAs on the Affymetrix GeneChip Human Gene 1.0 ST microarray with "cysteine-rich" in their gene name, none was enriched in the miRNP after miR-107 transfection relative to controls (see Supplemental Table S1 at $h$ ttp://ajp.amjpathol.org).

\section{Testing Different AGO miRNPs for miR-107: GRN mRNA}

Four different paralogous AGO proteins (AGOs 1-4) are expressed in humans. We examined whether our antiAGO antibody, which was raised against $A G O 2,{ }^{48}$ was

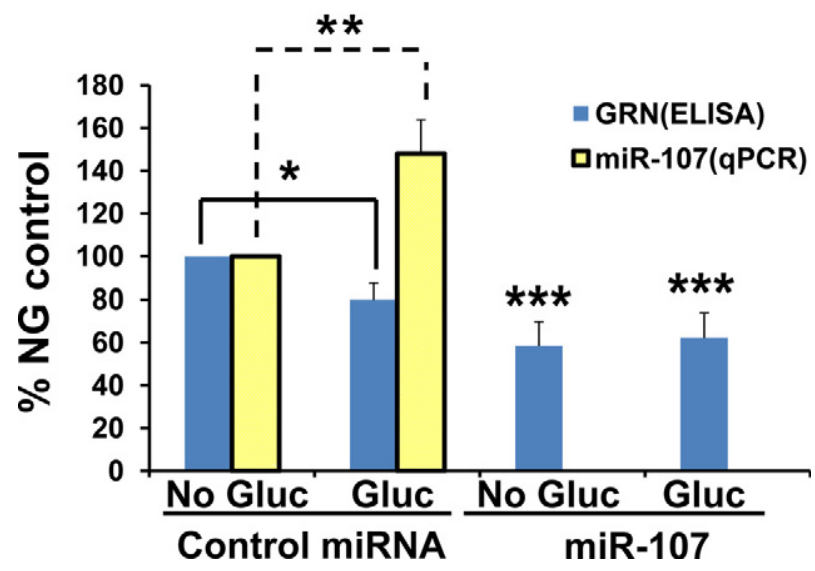

Figure 7. Glucose treatment is associated with decreased GRN secretion at least partly mediated through miR-107. H4 cells were transfected with 25 nmol/L miR-107 or a negative control miRNA precursor for 48 hours. Control cells were incubated in Dulbecco's modified Eagle medium cell media without glucose (NG) or supplemented with $10 \mathrm{mmol} / \mathrm{L}$ glucose. Glucose treatment has previously been shown to increase miR-107 expression. ${ }^{49}$ GRN in media was measured by ELISA, and the miR-107 levels in the cells were determined by qPCR with values normalized to 5S RNA. miR-107 levels (yellow bars) were up-regulated in response to glucose supplementation in cells transfected with control miRNA. Inversely, GRN (blue bars) was reduced in cell media following glucose supplementation. In cells transfected with miR-107, GRN levels in media are lower than in control NG, but GRN levels did not differ between NG and Gluc treated cells $(P>0.05)$. Data are average (relative to control) of two representative experiments with four replicates each. Statistical data were analyzed using Student's $t$-test. Comparing ELISA values, glucose versus NG: ${ }^{*} P<0.01$; ***** $P<0.0001$. Comparing miR- 107 values, glucose versus NG: ${ }^{* * a} P<0.006$; Error bars are standard errors of the means. causing bias in terms of detecting AGO-bound GRN and BACE1 mRNAs. miR-107 was co-transfected with plasmids that contain FLAG-tagged AGO constructs that were described previously. ${ }^{58}$ AGO4 is only lowly-expressed at the mRNA level in $\mathrm{H} 4$ cells and FLAG-tagged AGO4 did not express well in our hands despite multiple attempts (data not shown). GRN, BACE1, and $\beta$-Actin mRNA were not significantly bound to FLAG-AGO4 in those experiments (data not shown). Thus, only results of AGO1-AGO3 experiments are shown (Figure 6). ${ }^{58}$ FLAGAGO3 expresses at lower level than FLAG-AGO1 and FLAG-AGO2. However, downstream reverse transcription-qPCR was performed normalizing the overall RNA levels following anti-FLAG co-IPs. Following miR-107 transfections, the highest concentration of GRN mRNA was seen in FLAG-AGO2 co-IP, followed by FLAG-AGO1. mRNA for $\beta$-Actin and BACE1 were not detected in significant amounts in any FLAG-AGO co-IP. These data indicate that GRN mRNA appears to associate mainly with $A G O 2$ in miRNPs.

\section{The Effect of miR-107 on GRN Expression in Tissue Culture}

Tissue culture experiments were used to determine whether stimuli known to affect miR-107 also cause altered GRN secretion in cultured cells (Figure 7). ${ }^{49}$ The amount of GRN protein in the cell culture media was measured using an ELISA assay. ${ }^{50}$ Transfection of miR107 in $\mathrm{H} 4$ cells resulted in decreased GRN levels $(P<$

\section{Reporter assay: Rluc (GRN MREwt)/Rluc (GRN MREmut), DMEM + no glucose versus DMEM with $10 \mathrm{mM}$ glucose}

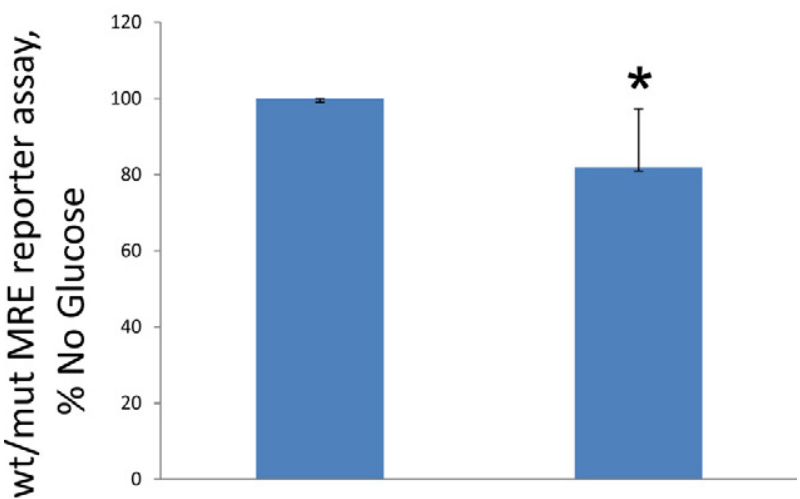

No Glucose Glucose-10mM

Figure 8. Glucose treatment in H4 cells resulted in reduced luciferase activity of reporter construct bearing GRN miR-107 recognition element. H4 cells were first transfected with reporter plasmids (nucleotides 892-974 on NM 002087.2, GRNwt and GRNmut, $N=6$ for each condition) along with transfection control plasmid pGL3. Cells were allowed to recover before 16-hour glucose treatment (10 $\mathrm{mmol} / \mathrm{L}$ or none). Dual luciferase reporter assays were performed. Relative GRNwt was normalized to GRNmut and taken as 100\% under "No Glucose" conditions. Data represents two individual experiments. Corrected luciferase signal is in arbitrary units. Rluc reporter with the GRNwt-containing sequence is knocked down relative to GRNmut in cells with $10 \mathrm{mmol} / \mathrm{L}$ glucose. Error bars are SD. ${ }^{*} P<0.01$ using one-tailed Student's $t$-test. 
$10^{-5}$ ) compared with GRN levels in negative control miRNA transfections. A prior study showed that changing glucose levels in tissue cultured cells leads to a selective increase in miR-107 expression. ${ }^{49}$ We used this paradigm for $\mathrm{H} 4$ cells and hypothesized that miR-107 increase would cause decreased GRN expression. As expected, glucose treatment led to increased miR-107 expression relative to cells with no glucose supplementation $(P<0.003)$. The ELISA assay confirmed that GRN levels were decreased following glucose supplementation $\left(P<10^{-5}\right)$. We compared the effects of glucose supplementation on GRN expression, in cells transfected with miR-107 relative to cells transfected with a control miRNA. Glucose supplementation did not further reduce GRN levels in miR-107 transfected cells, probably because miR-107 levels are very high and GRN is low in both of these conditions. These data suggest that the effect of glucose supplementation on GRN level is mediated at partly through miR-107. Finally, we hypothesized that glucose supplementation would lead to increased miR-107 which would knock down the luciferase reporter construct with the subcloned sequence corresponding to the open reading frame of GRN (nucleotides 892 to 974 on NM_002087.2). These experiments (Figure 8) show that the GRNwt mRNA derived sequence (versus the subtly-mutated GRNmut) indeed leads to specific attenuation of the reporter protein following glucose supplementation.

Since miR-107 transfection was associated with decreased GRN secretion, we hypothesized that miR-107 transfection might lead to altered cellular processing of GRN. Immunocytochemistry was performed on $\mathrm{H} 4$ cells (Supplemental Figure S3 at http://ajp.amjpathol.org). These studies showed that in cells transfected with a control miRNA (or no miRNA), the GRN immunocytochemistry showed a granular staining pattern that could be present throughout the cells' cytoplasm. Following miR-107 transfection, the staining became less granular throughout the cytoplasm and tended to be found in a "huff"-type pattern near to the cell nuclei (Supplemental Figure S3 at $h$ ttp://ajp.amjpathol.org).

\section{Studies of miR-107:GRN in the Mammalian Brain}

We sought to evaluate preliminarily whether miR-107 may contribute to mammalian brain GRN regulation. A basic consideration relates to the level of miRNA expression in the human brain. It has been shown previously that miR659 may also regulate GRN in the human brain. ${ }^{46}$ miRNA profiling experiments were performed to determine the expression levels of miR-107 relative to miR-659 and to other miRNAs in human cerebral cortex. RNA was isolated from gray matter from the superior and middle temporal cerebral cortical gyri (Brodmann Areas 21 and 22) of ten different nondemented human brains as described. ${ }^{25,56} \mathrm{cDNA}$ miRNA array experiments were then performed as described previously in detail. ${ }^{59,60}$ The arrays demonstrate that miR-107 is expressed at far higher levels than miR-659 in this brain area (array results and patient characteristics are shown in see Supplemental Figure $\mathrm{S} 4{ }^{59,60,93}$ at $h$ ttp://ajp.amjpathol.org).

An in vivo model was used to test whether a stimulus that affects miR-107 levels would also affect GRN protein expression (Figure 9, A-J). ${ }^{61}$ A prior study showed that miR-107 is specifically decreased in hippocampal Cornu Ammonis (CA) fields subjacent to cortical traumatic brain injury (TBI) at 24 hours after the injury. ${ }^{61}$ We hypothesized that this could be a model to test preliminarily if changes in miR-107 are associated with changes in GRN expression. We performed depth controlled cortical impact brain injury $(1.0 \mathrm{~mm})$ in the parietal cortex of mice $(N=7)$. A day after the injury, the mice were sacrificed and stained for miR-107 using in situ hybridization. As expected, neuronal miR-107 expression was decreased in the hippocampal CA1 and CA3 in the side ipsilateral to the injury, relative to the contralateral side and out of proportion to the change in neuronal staining using Nissl stain (Figure 9). Immunohistochemical stains were performed with a GRN antibody on near-serial sections. In inverse correlation to the decrease in neuronal miR-107 staining, the GRN protein expression showed an augmentation on the side ipsilateral to the injury. Note that the GRN expression is augmented in CA3 hippocampal neurons ipsilateral to the injury and is not only seen in leukocytes and microglial cells.

\section{Discussion}

The current study provides evidence that miR-107 helps regulate GRN expression in human cells. We were initially interested in assessing miR-107 targets due to prior experiments showing miR-107 is down-regulated in AD cerebral cortical gray matter. ${ }^{25}$ Surprisingly, RIP-Chip assays revealed that GRN mRNA is the strongest miR-107 target transcribed in cultured $\mathrm{H} 4$ cells. Further experiments support the hypothesis that the miR-107:GRN interactions are physiologically important (see Figure 10). miR-107 regulation of GRN appears to be relevant to glucose metabolism in cultured $\mathrm{H} 4$ cells, and we also found a correlative relationship between miR-107 and GRN expression in a mouse model of TBI. These experiments have implications about neurodegenerative diseases, cancer, and tissue-level responses to injury.

In addition to describing a novel mechanism of GRN regulation, our data also provide new information about how miRNAs interact with mRNAs. Since we had previously formulated hypotheses of miRNA targeting based on computational predictions, the observation that miR107 targets GRN was unexpected. Moreover, only two of the top fifteen strongest miR-107 targets detected in the RIP-Chip assay are predicted according to MicroCosm, TargetScan, or PicTar computational algorithms ${ }^{62-64}$ (other computational algorithms, rna22 ${ }^{21}$ and RNAhybrid $^{65}$, were also tested, and these did predict miR-107/ GRN binding although the predicted binding specificities were unclear). Furthermore, miR-107 appears to target GRN through sequences located in the open reading frame of GRN mRNA. The tendency for miRNAs to target 


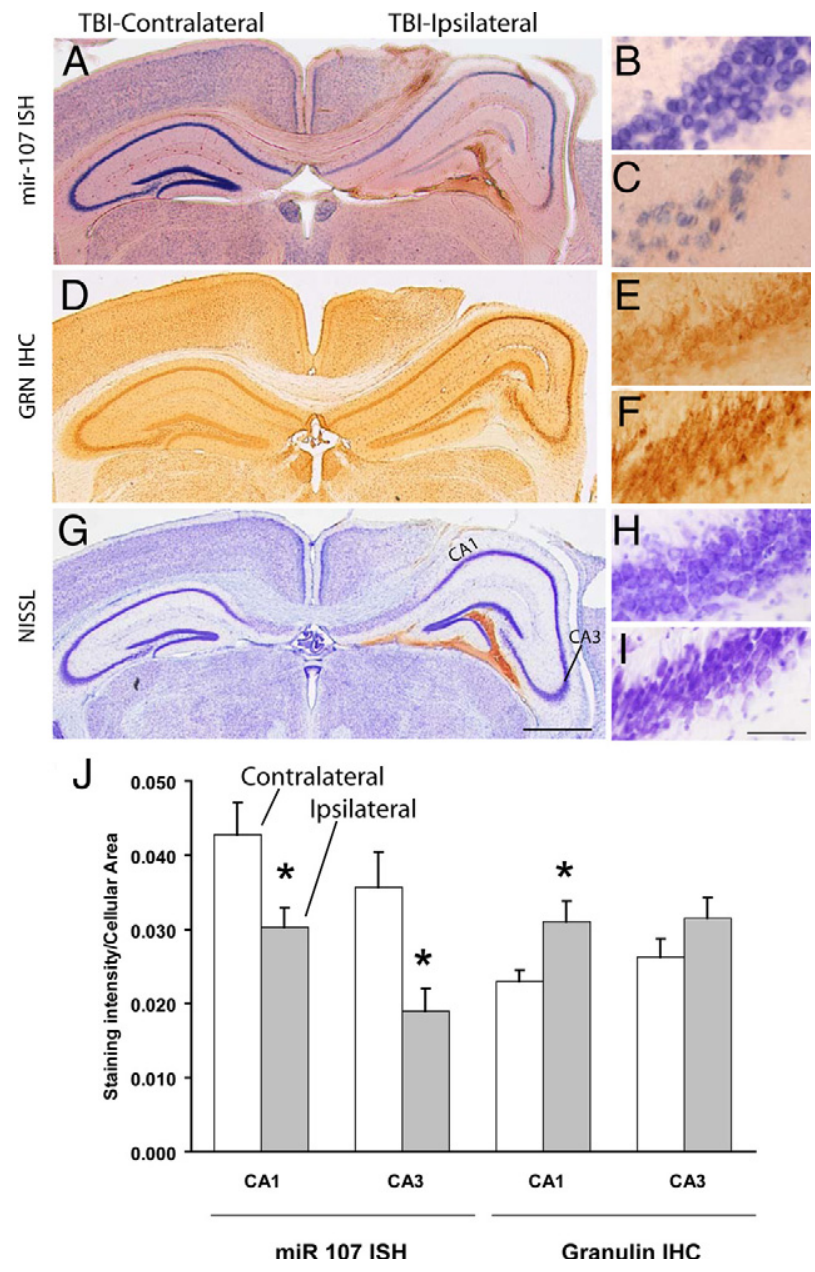

Figure 9. Assessing miR-107 and GRN expression in response to mouse traumatic brain injury (TBI). In 1.0-mm depth-controlled cortical impact experiments, miR-107 expression is decreased and GRN protein is increased in hippocampal neurons. A prior study had shown that hippocampal fields in TBI show decreased miR-107 expression 24 hours after injury. ${ }^{61}$ We hypothesized that diminished miR-107 expression would correlate with increased GRN protein levels. Note that in a representative case (A-I) miR-107 levels (A-C) are attenuated in ipsilateral hippocampal CA1 and CA3 fields, and GRN levels (D-F) are increased in near-serial sections, relative to the side contralateral to the injury. Higher-power photomicrographs $(\mathbf{B}, \mathbf{C}, \mathbf{E}, \mathbf{F}, \mathbf{H}, \mathbf{I})$ were taken from CA3 in an area indicated $(\mathbf{G})$. Scale bars $=500 \mu \mathrm{m}(\mathbf{A}, \mathbf{D}, \mathbf{G})$ and $50 \mu \mathrm{m}(\mathbf{B}, \mathbf{C}, \mathbf{E}, \mathbf{F}, \mathbf{H}, \mathbf{I})$. These changes were measured using unbiased methods in seven different mice. Only the hippocampal pyramidal layers (CA1 and CA3) were evaluated to prevent bias from the GRN-immunopositive microglial cells. Results of the quantitation are shown $(\mathbf{J})$. In this TBI model, miR-107 expression decreased relative to the contralateral side and GRN increased ( ${ }^{*} P<0.05$ by Student's $t$-test) in near-serial section hippocampal fields, compatible with the hypothesis that GRN expression changes are associated with altered miR-107. The intensity of staining per unit area is expressed as mean \pm SEM

regions outside the $3^{\prime} U T R$ has been described but is not known as a widespread phenomenon. ${ }^{66,67}$

There has been prior evidence of different AGO proteins associated with distinct miRNA targets. ${ }^{68,69}$ The strong association between AGO2 to GRN mRNA (especially after miR-107 transfection) provides greater detail about the molecular pathway of miR-107 targeting on GRN. This is the first example we know of a strong miRNA target that is associated preferentially with AGO2 in human neural-derived cells.

After determining that GRN gene expression is regulated in part by miR-107, we sought evidence as to

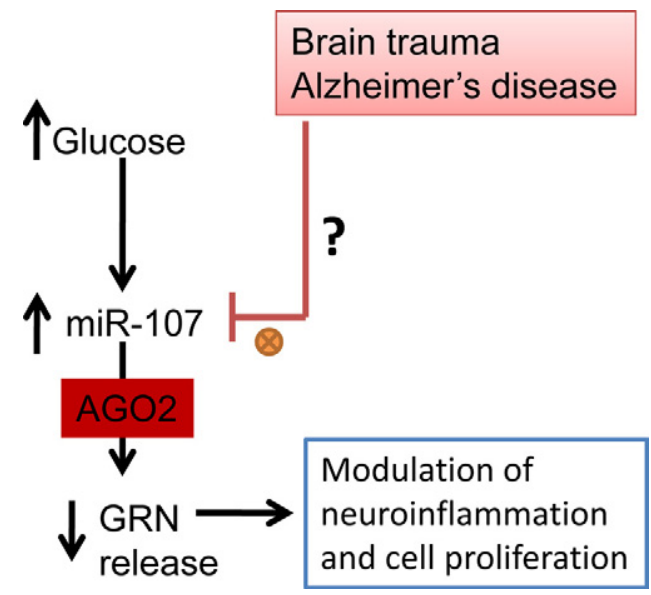

Figure 10. A schematic diagram about miR-107 and GRN. miR-107 and GRN may be important in linking glucose metabolism and brain disease, including neurodegeneration and brain trauma.

whether the interaction was physiologically relevant. Prior studies point to roles of miR-107 in cellular metabolism, ${ }^{49,70}$ with the caveat that naming a single discrete cellular function for a miRNA can be overly simplistic. Levels of miR-107 expression in cultured cells are relatively high in high-glucose or low-folate culture media conditions. ${ }^{49,71}$ In all known vertebrates, the genes for miR-107 and paralogous miR-103 reside within introns of pantothenate kinase paralog genes. Pantothenate kinase polypeptides catalyze the enzymatic rate-determining step in acetyl-CoA formation. ${ }^{70}$ Since most of the detection and functional assays would show extensive overlap with regard to miR-107 and miR-103 (see Figure 3), further discussion will refer to "miR-103/107" to include these genes together. When we perturb levels of glucose in the media of $\mathrm{H} 4$ cells, we found evidence that glucose metabolic pathways may recruit miR-103/107 to regulate GRN expression. Significantly, transfection of miR-107 into $\mathrm{H} 4$ cells led to lower GRN expression to such a degree that further regulation of GRN by glucose was no longer detectable.

Unlike miR-103/107, GRN has been studied extensively for decades. GRN has been implicated in numerous human illnesses including neoplastic and neurodegenerative disease. In multiple human cancers, including some brain cancers, GRN is a vital growth factor and/or demonstrates high expression. ${ }^{72-76}$ miR-107 has been shown to be repressed epigenetically in some cancer cells, ${ }^{77}$ which could cause substantially increased GRN protein levels - thereby potentiating tumor growth. Inhibition of miR-107 has been shown to cause increased growth of human lung adenocarcinoma cells, ${ }^{78}$ perhaps through this mechanism.

Genetic and pathological roles for GRN in neurodegeneration have also been suggested. We found miR107 decreased in AD brains. ${ }^{25}$ It would be interesting to know if this change correlates with altered neuronal GRN regulation that may contribute to $A D$ pathogenesis. ${ }^{79,80}$ However, GRN protein is expressed highly in glial and inflammatory cells, which are up-regulated in AD brain. ${ }^{81}$ Tissue-level analyses (eg, immunoblots of total brain ho- 
mogenates) would thus be in appropriate to study the connection between miR-107 and GRN expression because the question of cell type-specific GRN expression cannot be distinguished. GRN germline mutations are responsible for a subset of frontotemporal dementia (FTLD), ${ }^{43,44,82}$ which is a devastating neurological disease. In FTLD cases with GRN mutations, inheritance follows an autosomal dominant pattern and pathogenesis is thought to be due to GRN haploinsufficiency rather than a toxic gain of function mechanism. ${ }^{83,84}$ It is unknown whether miR-107 factors into that regulation. Also unknown is which of the pathways involving GRN are specifically responsible for the neuronal loss that occurs in FTLD. The RNA processing protein TDP-43 is aberrantly deposited in FTLD brains with GRN mutations so these cases are termed FTLD-TDP (although many FTLDTDP cases are not due to GRN mutations) ${ }^{85-87}$ In the current study, TDP-43 mRNA is transcribed at moderateto-high levels in $\mathrm{H} 4$ cell lysates (see Supplemental Table S1 at $h$ ttp://ajp.amjpathol.org). Using the RIP-Chip assay, we did not find TDP-43 mRNA incorporated into the AGOmiRNP, either after miR-107 or other miRNA transfections. A prior study provided support for the hypothesis that GRN is regulated by a human brain miRNA; a single nucleotide polymorphism in the GRN $3^{\prime} U T R$ can raise FTLD risk because that polymorphism alters miR-659 regulation of GRN. ${ }^{46}$ In the present study we show that expression levels of miR-103/107 is far higher than miR659 in the temporal cortex of ten elderly nondemented persons. Nevertheless, it is still possible that both miR103/107 and miR-659 act on GRN.

In contrast to the roles played in human diseases, GRN may contribute to wound healing and other normal brain functions. ${ }^{42,47,81}$ Here we found correlative support in a mouse model for the hypothesis that miR-107 expression decrease may contribute to an increased expression of GRN after TBI. We performed these experiments because it was shown previously that miR-107 is downregulated in rodent TBI. ${ }^{61}$ GRN protein expression is altered in ventral horn neurons in a mouse sciatic nerve axotomy model. ${ }^{88}$ Further, there is abundant evidence that GRN normally functions in wound repair outside the brain. $47,74,89$ We note that RIP-Chip identifies strong miR107 targets—-for example, meteorin and ninjurin — that are involved in axonal regeneration and extension. ${ }^{90-92}$ For these reasons, it is tempting to speculate that miR-107 plays a role in modulating neuronal repair and regeneration in the mammalian brain through molecular regulation of GRN and other mRNA targets.

Although strong regulation of GRN by miR-103/107 was demonstrated in the current study, there are some limitations to our approach. We used RIP-Chip assays on $\mathrm{H} 4$ cells. Derived from a brain tumor diagnosed as "neuroglioma" (a tumor classification no longer in use), H4 cells express a miRNA profile that more closely resembles cultured astrocytes than cultured neurons. ${ }^{55,56}$ As with any particular cell type, there are unavoidably many genes that are untranscribed that we could not evaluate for miRNA binding in the current study.

Aside from the inherent limitations of the cells used, RIP-Chip assays do not provide all of the information about miRNA:mRNA interactions. AGO-miRNPs have been shown to exert gene expression regulation via multiple mechanisms. ${ }^{17,93}$ For the mRNA to be "read out" on a microarray downstream of the anti-Ago co-IP, the target mRNA must be stably bound to the miRNP. When AGO2 works as a "slicer" to enzymatically cleave target mRNAs, ${ }^{94}$ one would expect a less stable miRNA:mRNA association and hence lower yield of mRNA targets. We note that BACE1 mRNA, which we have shown is targeted by miR-103/107 (including a description of a specific miRNA recognition element in BACE1 mRNA), ${ }^{25}$ is not specifically enriched in the RIP-Chip assay. However, we showed that BACE1 mRNA is specifically reduced in the lysates of miR-107 transfected cells, and miR-107 transfections indeed knock down BACE1 at the protein level. These observations are compatible with the hypothesis that a distinct mechanism other than stable AGO association is involved in miR-107:BACE1 regulation. Given the known multiple avenues of miRNA-based gene expression regulation, ${ }^{17,93,95}$ these results suggest that there are alternative pathways of miR-107 gene expression regulation. These pathways are a focus of ongoing research in our laboratory and may involve "slicing" or destabilization of BACE1 mRNA, a more tenuous association between BACE1 mRNA and AGO, or some other mechanism(s). Our results underscore once again that small noncoding RNAs are relevant to human disease, and that there is much yet to be learned about this complex mode of gene expression regulation.

\section{Acknowledgments}

We thank Dr. Zissimos Mourelatos for reagents and advice, Dr. Virginia Lee and Dr. Peter Davies for antibodies, and Dr. Thomas Tuschl for FLAG-tagged AGO plasmids.

\section{References}

1. Kosik KS, Krichevsky AM: The elegance of the microRNAs: a neuronal perspective. Neuron 2005, 47:779-782

2. Li N, Bates DJ, An J, Terry DA, Wang E: Up-regulation of key microRNAs, and inverse down-regulation of their predicted oxidative phosphorylation target genes, during aging in mouse brain. Neurobiol Aging 2009 doi: 10.1016/j.neurobiolaging.2009.04.020

3. Chang S, Wen S, Chen D, Jin P: Small regulatory RNAs in neurodevelopmental disorders. Hum Mol Genet 2009, 18:R18-R26

4. Nelson PT, Keller JN: RNA in brain disease: no longer just "the messenger in the middle." J Neuropathol Exp Neurol 2007, $66: 461-468$

5. Heimberg AM, Sempere LF, Moy VN, Donoghue PC, Peterson KJ: MicroRNAs and the advent of vertebrate morphological complexity. Proc Natl Acad Sci USA 2008, 105:2946-2950

6. Schaefer A, O'Carroll D, Tan CL, Hillman D, Sugimori M, Llinas R Greengard P: Cerebellar neurodegeneration in the absence of microRNAs. J Exp Med 2007, 204:1553-1558

7. Cuellar TL, Davis TH, Nelson PT, Loeb GB, Harfe BD, Ullian E, McManus MT: Dicer loss in striatal neurons produces behavioral and neuroanatomical phenotypes in the absence of neurodegeneration. Proc Natl Acad Sci USA 2008, 105:5614-5619

8. Bilen J, Liu N, Burnett BG, Pittman RN, Bonini NM: MicroRNA pathways modulate polyglutamine-induced neurodegeneration. Mol Cell 2006, 24:157-163

9. Ahmed FE: Role of miRNA in carcinogenesis and biomarker selection: a methodological view. Expert Rev Mol Diagn 2007, 7:569-603 
10. Cummins JM, Velculescu VE: Implications of micro-RNA profiling for cancer diagnosis. Oncogene 2006, 25:6220-6227

11. Wei JJ, Soteropoulos P: MicroRNA: a new tool for biomedical risk assessment and target identification in human uterine leiomyomas. Semin Reprod Med 2008, 26:515-521

12. Hugon J, Paquet C: Targeting miRNAs in Alzheimer's disease. Expert Rev Neurother 2008, 8:1615-1616

13. Nelson PT, Wang WX, Rajeev BW: MicroRNAs (miRNAs) in neurodegenerative diseases. Brain Pathol 2008, 18:130-138

14. Hebert SS, De Strooper B: Alterations of the microRNA network cause neurodegenerative disease. Trends Neurosci 2009, 32:199-206

15. Hutvagner G, Simard MJ: Argonaute proteins: key players in RNA silencing. Nat Rev Mol Cell Biol 2008, 9:22-32

16. Ambros V: The functions of animal microRNAs. Nature 2004 431:350-355

17. Liu X, Fortin K, Mourelatos Z: MicroRNAs: biogenesis and molecular functions. Brain Pathol 2008, 18:113-121

18. Carmell MA, Xuan Z, Zhang MQ, Hannon GJ: The Argonaute family: tentacles that reach into RNAi, developmental control, stem cell maintenance, and tumorigenesis. Genes Dev 2002, 16:2733-2742

19. Baek D, Villen J, Shin C, Camargo FD, Gygi SP, Bartel DP: The impact of microRNAs on protein output. Nature 2008, 455:64-71

20. Farh KK, Grimson A, Jan C, Lewis BP, Johnston WK, Lim LP, Burge CB, Bartel DP: The widespread impact of mammalian MicroRNAs on mRNA repression and evolution. Science 2005, 310:1817-1821

21. Miranda KC, Huynh T, Tay Y, Ang YS, Tam WL, Thomson AM, Lim B, Rigoutsos I: A pattern-based method for the identification of MicroRNA binding sites and their corresponding heteroduplexes. Cell 2006, 126:1203-1217

22. Bartel DP: MicroRNAs: target recognition and regulatory functions. Cell 2009, 136:215-233

23. Kim J, Inoue K, Ishii J, Vanti WB, Voronov SV, Murchison E, Hannon G, Abeliovich A: A MicroRNA feedback circuit in midbrain dopamine neurons. Science 2007, 317:1220-1224

24. Lukiw WJ: Micro-RNA speciation in fetal, adult and Alzheimer's disease hippocampus. Neuroreport 2007, 18:297-300

25. Wang WX, Rajeev BW, Stromberg AJ, Ren N, Tang G, Huang Q, Rigoutsos I, Nelson PT: The expression of microRNA miR-107 decreases early in Alzheimer's disease and may accelerate disease progression through regulation of beta-site amyloid precursor protein-cleaving enzyme 1. J Neurosci 2008, 28:1213-1223

26. Nelson PT, Hatzigeorgiou AG, Mourelatos Z: miRNP:mRNA association in polyribosomes in a human neuronal cell line. RNA 2004, 10:387-394

27. Mourelatos Z, Dostie J, Paushkin S, Sharma A, Charroux B, Abel L, Rappsilber J, Mann M, Dreyfuss G: miRNPs: a novel class of ribonucleoproteins containing numerous microRNAs. Genes Dev 2002, 16:720-728

28. Beitzinger M, Peters L, Zhu JY, Kremmer E, Meister G: Identification of human microRNA targets from isolated argonaute protein complexes. RNA Biol 2007, 4:76-84

29. Easow G, Teleman AA, Cohen SM: Isolation of microRNA targets by miRNP immunopurification. RNA 2007, 13:1198-1204

30. Karginov FV, Conaco C, Xuan Z, Schmidt BH, Parker JS, Mandel G, Hannon GJ: A biochemical approach to identifying microRNA targets. Proc Natl Acad Sci USA 2007, 104:19291-19296

31. Andachi Y: A novel biochemical method to identify target genes of individual microRNAs: identification of a new Caenorhabditis elegans let-7 target. RNA 2008, 14:2440-2451

32. Landthaler M, Gaidatzis D, Rothballer A, Chen PY, Soll SJ, Dinic L, Ojo T, Hafner M, Zavolan M, Tuschl T: Molecular characterization of human Argonaute-containing ribonucleoprotein complexes and their bound target mRNAs. RNA 2008, 14:2580-2596

33. Hendrickson DG, Hogan DJ, Herschlag D, Ferrell JE, Brown PO: Systematic identification of mRNAs recruited to argonaute 2 by specific microRNAs and corresponding changes in transcript abundance. PLoS ONE 2008, 3:e2126

34. Chi SW, Zang JB, Mele A, Darnell RB: Argonaute HITS-CLIP decodes microRNA-mRNA interaction maps. Nature 2009, 460:479-486

35. Keene JD, Komisarow JM, Friedersdorf MB: RIP-Chip: the isolation and identification of mRNAs, microRNAs and protein components of ribonucleoprotein complexes from cell extracts. Nat Protoc 2006, 1:302-307

36. Tan LP, Seinen E, Duns G, de Jong D, Sibon OC, Poppema S,
Kroesen BJ, Kok K, van den Berg A: A high throughput experimental approach to identify miRNA targets in human cells. Nucleic Acids Res 2009, 37:e137

37. Wang WX, Wilfred BR, Hu Y, Stromberg AJ, Nelson PT: Anti-Argonaute RIP-Chip shows that miRNA transfections alter global patterns of mRNA recruitment to microribonucleoprotein complexes. RNA 2010, 16:394-404

38. Liscic RM, Grinberg LT, Zidar J, Gitcho MA, Cairns NJ: ALS and FTLD: two faces of TDP-43 proteinopathy. Eur J Neurol 2008, 15:772-780

39. Serrero G: Autocrine growth factor revisited: $\mathrm{pC}$-cell-derived growth factor (progranulin), a critical player in breast cancer tumorigenesis. Biochem Biophys Res Commun 2003, 308:409-413

40. Suzuki M, Nishiahara M: Granulin precursor gene: a sex steroidinducible gene involved in sexual differentiation of the rat brain. Mol Genet Metab 2002, 75:31-37

41. He Z, Bateman A: Progranulin (granulin-epithelin precursor. PC-cellderived growth factor, acrogranin) mediates tissue repair and tumorigenesis. J Mol Med 2003, 81:600-612

42. Bateman A, Bennett HP: The granulin gene family: from cancer to dementia. Bioessays 2009, 31:1245-1254

43. Baker M, Mackenzie IR, Pickering-Brown SM, Gass J, Rademakers R, Lindholm C, Snowden J, Adamson J, Sadovnick AD, Rollinson S, Cannon A, Dwosh E, Neary D, Melquist S, Richardson A, Dickson D, Berger Z, Eriksen J, Robinson T, Zehr C, Dickey CA, Crook R, McGowan E, Mann D, Boeve B, Feldman H, Hutton M: Mutations in progranulin cause tau-negative frontotemporal dementia linked to chromosome 17. Nature 2006, 442:916-919

44. Cruts M, Kumar-Singh S, Van Broeckhoven C: Progranulin mutations in ubiquitin-positive frontotemporal dementia linked to chromosome 17q21. Curr Alzheimer Res 2006, 3:485-491

45. Gass J, Cannon A, Mackenzie IR, Boeve B, Baker M, Adamson J, Crook R, Melquist S, Kuntz K, Petersen R, Josephs K, PickeringBrown SM, Graff-Radford N, Uitti R, Dickson D, Wszolek Z, Gonzalez J, Beach TG, Bigio E, Johnson N, Weintraub S, Mesulam M, White CL 3rd, Woodruff B, Caselli R, Hsiung GY, Feldman H, Knopman D, Hutton M, Rademakers R: Mutations in progranulin are a major cause of ubiquitin-positive frontotemporal lobar degeneration. Hum Mol Genet 2006, 15:2988-3001

46. Rademakers R, Eriksen JL, Baker M, Robinson T, Ahmed Z, Lincoln SJ, Finch N, Rutherford NJ, Crook RJ, Josephs KA, Boeve BF, Knopman DS, Petersen RC, Parisi JE, Caselli RJ, Wszolek ZK, Uitti RJ, Feldman H, Hutton ML, Mackenzie IR, Graff-Radford NR, Dickson DW: Common variation in the miR-659 binding-site of GRN is a major risk factor for TDP43-positive frontotemporal dementia. Hum Mol Genet 2008, 17:3631-3642

47. Eriksen JL, Mackenzie IR: Progranulin: normal function and role in neurodegeneration. J Neurochem 2008, 104:287-297

48. Nelson PT, De Planell-Saguer M, Lamprinaki S, Kiriakidou M, Zhang P, O'Doherty U, Mourelatos Z: A novel monoclonal antibody against human Argonaute proteins reveals unexpected characteristics of miRNAs in human blood cells. RNA 2007, 13:1787-1792

49. Tang X, Muniappan L, Tang G, Ozcan S: Identification of glucoseregulated miRNAs from pancreatic $\{$ beta\} cells reveals a role for miR-30d in insulin transcription. RNA 2009, 15:287-293

50. Van Damme P, Van Hoecke A, Lambrechts D, Vanacker P, Bogaert E, van Swieten J, Carmeliet P, Van Den Bosch L, Robberecht W: Progranulin functions as a neurotrophic factor to regulate neurite outgrowth and enhance neuronal survival. J Cell Biol 2008, 181:37-41

51. Huh JW, Laurer HL, Raghupathi R, Helfaer MA, Saatman KE: Rapid loss and partial recovery of neurofilament immunostaining following focal brain injury in mice. Exp Neurol 2002, 175:198-208

52. Saatman KE, Feeko KJ, Pape RL, Raghupathi R: Differential behavioral and histopathological responses to graded cortical impact injury in mice. J Neurotrauma 2006, 23:1241-1253

53. Nelson PT, Baldwin DA, Kloosterman WP, Kauppinen S, Plasterk RH, Mourelatos Z: RAKE and LNA-ISH reveal microRNA expression and localization in archival human brain. RNA 2006, 12:187-191

54. Nelson PT, Wilfred BR: In situ hybridization is a necessary experimental complement to microRNA (miRNA) expression profiling in the human brain. Neurosci Lett 2009, 466:69-72

55. Arnstein P, Taylor DO, Nelson-Rees WA, Huebner RJ, Lennette EH Propagation of human tumors in antithymocyte serum-treated mice. J Natl Cancer Inst 1974, 52:71-84 
56. Wang WX, Wilfred BR, Baldwin DA, Isett RB, Ren N, Stromberg A, Nelson PT: Focus on RNA isolation: obtaining RNA for microRNA (miRNA) expression profiling analyses of neural tissue. Biochim Biophys Acta 2008, 1779:749-757

57. Pesole G, Liuni S, Grillo G, Saccone C: Structural and compositional features of untranslated regions of eukaryotic mRNAs. Gene 1997, 205:95-102

58. Meister G, Landthaler M, Patkaniowska A, Dorsett $\mathrm{Y}$, Teng G, Tuschl T: Human argonaute2 mediates RNA cleavage targeted by miRNAs and siRNAs. Mol Cell 2004, 15:185-197

59. Nelson PT, Wang WX, Wilfred BR, Tang G: Technical variables in high-throughput miRNA expression profiling: much work remains to be done. Biochim Biophys Acta 2008, 1779:758-765

60. Tang X, Gal J, Zhuang X, Wang W, Zhu H, Tang G: A simple array platform for microRNA analysis and its application in mouse tissues. RNA 2007, 13:1803-1822

61. Redell JB, Liu Y, Dash PK: Traumatic brain injury alters expression of hippocampal microRNAs: potential regulators of multiple pathophysiological processes. J Neurosci Res 2009, 87:1435-1448

62. Enright AJ, John B, Gaul U, Tuschl T, Sander C, Marks DS: MicroRNA targets in Drosophila. Genome Biol 2003, 5:R1

63. Krek A, Grun D, Poy MN, Wolf R, Rosenberg L, Epstein EJ, MacMenamin P, da Piedade I, Gunsalus KC, Stoffel M, Rajewsky N: Combinatorial microRNA target predictions. Nat Genet 2005, 37:495-500

64. Lewis BP, Burge CB, Bartel DP: Conserved seed pairing, often flanked by adenosines, indicates that thousands of human genes are microRNA targets. Cell 2005, 120:15-20

65. Hsu SD, Chu CH, Tsou AP, Chen SJ, Chen HC, Hsu PW, Wong YH, Chen YH, Chen GH, Huang HD: miRNAMap 2.0: genomic maps of microRNAs in metazoan genomes. Nucleic Acids Res 2008, 36:D165-D169

66. Rigoutsos I: New tricks for animal microRNAS: targeting of amino acid coding regions at conserved and nonconserved sites. Cancer Res 2009, 69:3245-3248

67. Orom UA, Nielsen FC, Lund AH: MicroRNA-10a binds the $5^{\prime}$ UTR of ribosomal protein mRNAs and enhances their translation. Mol Cell 2008, 30:460-471

68. Weinmann L, Hock J, Ivacevic T, Ohrt T, Mutze J, Schwille P, Kremmer E, Benes V, Urlaub H, Meister G: Importin 8 is a gene silencing factor that targets argonaute proteins to distinct mRNAs. Cell 2009, 136:496-507

69. Su H, Trombly MI, Chen J, Wang X: Essential and overlapping functions for mammalian argonautes in microRNA silencing. Genes Dev 2009, 23:304-317

70. Wilfred BR, Wang WX, Nelson PT: Energizing miRNA research: a review of the role of miRNAs in lipid metabolism, with a prediction that miR-103/107 regulates human metabolic pathways. Mol Genet Metab 2007, 91:209-217

71. Marsit CJ, Eddy K, Kelsey KT: MicroRNA responses to cellular stress. Cancer Res 2006, 66:10843-10848

72. Lu R, Serrero G: Inhibition of PC cell-derived growth factor (PCDGF, epithelin/granulin precursor) expression by antisense PCDGF cDNA transfection inhibits tumorigenicity of the human breast carcinoma cell line MDA-MB-468. Proc Natl Acad Sci USA 2000, 97:3993-3998

73. Xu SQ, Tang D, Chamberlain S, Pronk G, Masiarz FR, Kaur S, Prisco M, Zanocco-Marani T, Baserga R: The granulin/epithelin precursor abrogates the requirement for the insulin-like growth factor 1 receptor for growth in vitro. J Biol Chem 1998, 273:20078-20083

74. Zanocco-Marani T, Bateman A, Romano G, Valentinis B, He ZH, Baserga R: Biological activities and signaling pathways of the granulin/epithelin precursor. Cancer Res 1999, 59:5331-5340

75. Donald CD, Laddu A, Chandham P, Lim SD, Cohen C, Amin M, Gerton GL, Marshall FF, Petros JA: Expression of progranulin and the epithelin/granulin precursor acrogranin correlates with neoplastic state in renal epithelium. Anticancer Res 2001, 21:3739-3742

76. Liau LM, Lallone RL, Seitz RS, Buznikov A, Gregg JP, Kornblum HI, Nelson SF, Bronstein JM: Identification of a human glioma-associated growth factor gene, granulin, using differential immuno-absorption. Cancer Res 2000, 60:1353-1360

77. Lee KH, Lotterman C, Karikari C, Omura N, Feldmann G, Habbe N, Goggins MG, Mendell JT, Maitra A: Epigenetic silencing of MicroRNA miR-107 regulates cyclin-dependent kinase 6 expression in pancreatic cancer. Pancreatology 2009, 9:293-301
78. Cheng AM, Byrom MW, Shelton J, Ford LP: Antisense inhibition of human miRNAs and indications for an involvement of miRNA in cell growth and apoptosis. Nucleic Acids Res 2005, 33:1290-1297

79. Brouwers N, Sleegers K, Engelborghs S, Maurer-Stroh S, Gijselinck I, van der Zee J, Pickut BA, Van den Broeck M, Mattheijssens M, Peeters K, Schymkowitz J, Rousseau F, Martin JJ, Cruts M, De Deyn PP, Van Broeckhoven C: Genetic variability in progranulin contributes to risk for clinically diagnosed Alzheimer disease. Neurology 2008, 71:656-664

80. Pereson S, Wils H, Kleinberger G, McGowan E, Vandewoestyne M, Van Broeck B, Joris G, Cuijt I, Deforce D, Hutton M, Van Broeckhoven C, Kumar-Singh S: Progranulin expression correlates with dense-core amyloid plaque burden in Alzheimer disease mouse models. J Pathol 2009, 219:173-181

81. Ahmed Z, Mackenzie IR, Hutton ML, Dickson DW: Progranulin in frontotemporal lobar degeneration and neuroinflammation. J Neuroinflammation 2007, 4:7

82. Snowden JS, Pickering-Brown SM, Mackenzie IR, Richardson AM, Varma A, Neary D, Mann DM: Progranulin gene mutations associated with frontotemporal dementia and progressive non-fluent aphasia. Brain 2006, 129:3091-3102

83. Masellis M, Momeni P, Meschino W, Heffner R Jr, Elder J, Sato C, Liang Y, St George-Hyslop P, Hardy J, Bilbao J, Black S, Rogaeva E: Novel splicing mutation in the progranulin gene causing familial corticobasal syndrome. Brain 2006, 129:3115-3123

84. Cruts M, Gijselinck I, van der Zee J, Engelborghs S, Wils H, Pirici D, Rademakers R, Vandenberghe R, Dermaut B, Martin JJ, van Duijn C, Peeters K, Sciot R, Santens P, De Pooter T, Mattheijssens M, Van den Broeck M, Cuijt I, Vennekens K, De Deyn PP, Kumar-Singh S, Van Broeckhoven C: Null mutations in progranulin cause ubiquitin-positive frontotemporal dementia linked to chromosome 17q21. Nature 2006, 442:920-924

85. Neumann M, Sampathu DM, Kwong LK, Truax AC, Micsenyi MC Chou TT, Bruce J, Schuck T, Grossman M, Clark CM, McCluskey LF, Miller BL, Masliah E, Mackenzie IR, Feldman H, Feiden W, Kretzschmar HA, Trojanowski JQ, Lee VM: Ubiquitinated TDP-43 in frontotemporal lobar degeneration and amyotrophic lateral sclerosis. Science 2006, 314:130-133

86. Van Deerlin VM, Wood EM, Moore P, Yuan W, Forman MS, Clark CM, Neumann M, Kwong LK, Trojanowski JQ, Lee VM, Grossman M: Clinical, genetic, and pathologic characteristics of patients with frontotemporal dementia and progranulin mutations. Arch Neurol 2007, 64:1148-1153

87. Cairns NJ, Bigio EH, Mackenzie IR, Neumann M, Lee VM, Hatanpaa KJ, White CL, 3rd, Schneider JA, Grinberg LT, Halliday G, Duyckaerts C, Lowe JS, Holm IE, Tolnay M, Okamoto K, Yokoo H, Murayama S, Woulfe J, Munoz DG, Dickson DW, Ince PG, Trojanowski JQ, Mann DM: Neuropathologic diagnostic and nosologic criteria for frontotemporal lobar degeneration: consensus of the Consortium for Frontotemporal Lobar Degeneration. Acta Neuropathol (Berl) 2007, 114:5-22

88. Moisse K, Volkening K, Leystra-Lantz C, Welch I, Hill T, Strong MJ Divergent patterns of cytosolic TDP-43 and neuronal progranulin expression following axotomy: implications for TDP-43 in the physiological response to neuronal injury. Brain Res 2009, 1249:202-211

89. Tolkatchev D, Malik S, Vinogradova A, Wang P, Chen Z, Xu P, Bennett $\mathrm{HP}$, Bateman A, Ni F: Structure dissection of human progranulin identifies well-folded granulin/epithelin modules with unique functional activities. Protein Sci 2008, 17:711-724

90. Araki T, Milbrandt J: Ninjurin, a novel adhesion molecule, is induced by nerve injury and promotes axonal growth. Neuron 1996, 17:353-361

91. Kubo T, Yamashita T, Yamaguchi A, Hosokawa K, Tohyama M: Analysis of genes induced in peripheral nerve after axotomy using cDNA microarrays. J Neurochem 2002, 82:1129-1136

92. Nishino J, Yamashita K, Hashiguchi H, Fujii H, Shimazaki T, Hamada $\mathrm{H}$ : Meteorin: a secreted protein that regulates glial cell differentiation and promotes axonal extension. EMBO J 2004, 23:1998-2008

93. Wang W, Nelson PT, Tang G: RNA interference, mechanisms and proteins involved in. New York: John Wiley \& Sons, Inc., 2008, p.1-10

94. Liu J, Carmell MA, Rivas FV, Marsden CG, Thomson JM, Song JJ, Hammond SM, Joshua-Tor L, Hannon GJ: Argonaute2 is the catalytic engine of mammalian RNAi. Science 2004, 305:1437-1441

95. Makeyev EV, Maniatis T: Multilevel regulation of gene expression by microRNAs. Science 2008, 319:1789-1790 